\title{
Politics, ecology, and the new anthropology of energy: exploring the emerging frontiers of hydraulic fracking
}

\author{
Anna J. Willow ${ }^{1}$ \\ Sara Wylie \\ Ohio State University, USA \\ Northeastern University, USA
}

\begin{abstract}
This article reviews recent literature relevant to the ongoing shale gas boom and introduces the Journal of Political Ecology's Special Section on hydraulic fracking. We highlight the need for ethnographic studies of the tumultuous social and physical transformations resulting from, and produced by, an unfolding frontier of energy production that unsettles social, economic, and ecological landscapes. We examine how intercommunity connections are vital to recognizing the shared structural conditions produced by the oil and gas industry's expansion, through examining the roles played by the oil field services industry, the sequestration of information and agnotology (the deliberate production of ignorance), divide and conquer tactics, and shared experiences of risk and embodied effects. Summarizing the contributions of the five articles included in the Special Section, we offer recommendations for further inquiry. We examine how social science studies of hydraulic fracking are producing new and innovative methodologies for developing participatory academic and community research projects.
\end{abstract}

Key words: digital media, embodiment, energy, hydraulic fracturing, oil field services industry, shale gas

\section{Résumé}

Cet article est une revue de la littérature récente pertinente sur le boom du gaz de schiste, pour cette section spéciale dans le Journal of Political Ecology sur la fracturation hydraulique. Nous soulignons la nécessité d'études ethnographiques des transformations sociales et physiques résultant d'une déroulement de la production d'énergie qui déstabilise les paysages sociaux, économiques et écologiques. Nous examinons comment c'est essentiel a reconnaître les similitudes structurelles existent entre les différentes communautés par l'expansion de l'industrie du pétrole et du gaz. Conclusions importantes concerne les rôles joués par le secteur des services de champ pétrolier, la séquestration de l'information et agnotology (la production délibérée de l'ignorance), les tactiques de diviser et conquérir, et les expériences partagées de risques et effets intrinsèques. Résumant les contributions des cinq articles inclus dans la section spéciale, nous concluons avec des recommandations pour des enquêtes plus approfondie. Enfin, nous examinons comment les études en sciences sociales de la fracturation hydraulique produisent de nouvelles méthodes pour le développement de projets de recherche universitaires et communautaires participatives.

Mots clés: médias numériques, l'énergie, la fracturation hydraulique, l'industrie des services pétroliers, le gaz de schiste

\section{Resumen}

Este artículo revisa la literatura reciente en curso y relevante al auge del "gas de esquisto" para esta sección especial sobre fractura hidráulica del Journal of Political Ecology. Destacamos la necesidad de estudios etnográficos acerca de las transformaciones tumultuosas sociales y físicas resultantes de y producidas por el despliegue de la producción energética que perturba los paisajes sociales, económicos y ecológicos. Examinamos como las conexiones entre las comunidades son vitales para el reconocimiento de las

\footnotetext{
${ }^{1}$ Dr. Anna Willow, Assistant Professor, Department of Anthropology, Ohio State University, USA. Email: willow.1 "at" osu.edu. Dr. Sara Wylie, Assistant Professor of Sociology/Anthropology and Health Sciences, Social Science Environmental Health Research Institute, Northeastern University, USA Email: s.wylie "at" neu.edu. We thank the many article reviewers for the Section. This is the introduction to Willow, A.J. and Wylie, S. (eds.) 2014. "Energy, environment, engagement: encounters with hydraulic fracking", special section of the Journal of Political Ecology 21: 222-348.
} 
condiciones estructurales compartidas y producidas por la expansión de la industria del petróleo y gas, esto mediante la exanimación de las funciones desempeñadas por las industrias de servicios petroleros, el posicionamiento ilícito de información y la agnotología (producción deliberada de ignorancia), técnicas de división y conquista, al igual que experiencias compartidas de riesgo y efectos incorporados. Resumiendo las contribuciones de los cinco artículos incluidos en la sección especial ofrecemos recomendaciones para consultas posteriores. Examinamos como los estudios de ciencias sociales sobre fractura hidráulica están produciendo nuevas e innovadoras metodologías para el desarrollo de proyectos de investigación académicos y proyectos comunitarios participativos.

Palabras claves: Medios de comunicación, personificación, energía, fracturamiento hidráulico, industrias de servicios petrolíferos, gas de esquisto (shale gas)

\section{What is fracking and why is its relevant?}

Technological advances have made it possible and profitable to extract fossil fuels (especially natural gas, but also oil and coalbed methane) that were until recently believed to be out of reach. In the past decade, a technique borne of the merger of hydraulic fracturing and horizontal drilling — known in the industry as high-volume slick water horizontal hydrofracturing - has been exported from the United States to every inhabited continent on earth. This process (colloquially and hereafter known as fracking) entails pumping a mixture of water, proppants (silica sand and/or manufactured granules used to prop rock fractures open), and assorted chemicals deep into the ground at high pressure. As a result, small fractures are produced in the target rock layer, releasing the hydrocarbons contained within. In some places, the resulting rush to extract these resources has already significantly altered physical environments, economic systems, community structures, and human health. Although proponents have celebrated unconventional fossil fuel development as a key to energy independence and a critical catalyst for economic recovery, it has numerous detractors (MITEI 2011).

It is not merely its abrasive sound that led environmentalist author Bill McKibben (2011) to declare fracking "the ugliest word in the English language." As indicated by the intensity of ongoing anti-fracking campaigns - some of them documented in this special section-many seem to agree. Commonly voiced ecological and human health concerns surround water quality and availability, discharges of toxic substances into the environment, air emissions released during production and processing, explosions from methane build-up, and earthquakes. While actual and potential environmental degradation resulting from fracking has received a significant amount of scholarly attention (e.g., Entrekin et al. 2011; Holzman 2011; Howarth, Santoro, and Ingraffea 2010; Jackson et al. 2013; McKenzie et al. 2012; Osborn et al. 2011) and is currently being investigated by the United States Environmental Protection Agency (2012), equally devastating —and clearly interrelated—sociocultural consequences have been comparatively overlooked. ${ }^{2}$

The number of published social science studies on the impacts of fracking is steadily growing. Much of this work, however, has been informed by quantitative survey methods rather than qualitative ethnographic inquiry (e.g., Anderson and Theodori 2009; Brasier et al. 2011; Jacquet 2012; Theodori 2009). Notable exceptions include Simona Perry's comparative consideration of the place-based consequences of regional and national energy politics in the "global countryside" (2011), Perry's more direct demonstration of ethnography's value as a tool for monitoring community health in unconventional energy production zones (2013; see also Wylie 2011), recent examinations of the political production and/or obfuscation of risk in the face of uncertainty about fracking's actual effects (Cartwright 2013; Finewood and Stroup 2012), and ethnographic overviews of unfolding conflicts surrounding unconventional extraction (e.g., de Rijke 2013a, 2013b; Pearson 2013; Willow et al. 2014). These articles have added valuable voices to the conversation and, in the process, made a strong case for qualitative research on fracking. Still, critical analyses that

\footnotetext{
2 The EPA released a progress report in 2012 and is expected to release a draft of the compete study for public comment and peer-review later this year. For more information and updates, see http://www2.epa.gov/hfstudy [accessed February 22 2014].
} 
illuminate the consequences, implications, and cultural practices associated with fracking have yet to appear in significant volumes. ${ }^{3}$ This Special Section aims to fill this gap.

The articles included here have their origins in two overlapping organized conference sessions that took place in late 2012 and early 2013. Recognizing the need to foster coordination and communication among anthropologists seeking to understand the social and cultural impacts of ongoing unconventional energy development, Anna Willow (of the Ohio State University) organized a panel on the theme of hydraulic fracking for the November 2012 American Anthropological Association meeting in San Francisco, California. Sara Wylie (of Northeastern University) served as a discussant for this panel. Thomas Pearson (of the University of Wisconsin-Stout) organized a similar panel and a productive roundtable discussion for the March 2013 meeting of the Society for Applied Anthropology, held in Denver, Colorado. These events led to the development of a new (and still growing) scholarly network, sowed the seeds of fruitful collaborative relationships, and revealed widespread interest in this timely topic.

Fracking merits close social scientific attention. As it proliferates, impacts are poised to increase exponentially, not only in extraction zones but also throughout the global system that supplies the oil and gas industry and demands the continued production of fossil fuel energy. Because commodity-chain effects are experienced worldwide and because national and international political and economic decisions have emplaced implications, the anthropology of hydraulic fracking demands attention to global connection as well as local specificity. Presenting perspectives from New York, Ohio, Pennsylvania, and Australia, the articles that follow approach the cultural contexts and consequences of hydraulic fracking with numerous questions in mind: How are community structures, social networks, land use decisions, and the cultural meanings of rural landscapes changing as a result of fracking? How is ongoing and impending energy development transforming people's experiences and understandings of the landscapes they inhabit, utilize, and/or work to protect? How do the human impacts of resource extraction converge and diverge over time and space? What new dialogues, political formations, social movements, and alliances are emerging, and which discussions and discourses are being emphasized or obscured? How can new ethnographic formats deepen our understanding of these changes?

In the United States and beyond, the rapid intensification of fracking provides a new and urgent lens through which to explore the diversity, dynamism, and politics of human-environment relationships. Increased scrutiny of oil and gas activity has resulted in new prospects for collaborative mobilization and inspired academic studies aimed at influencing environmental public policy and industrial practices. With uneven transformations in regulatory terrain alternatively designed to speed, moderate, or halt development, exciting new opportunities are emerging for comparative case studies in anthropology, public policy, and environmental history. ${ }^{4}$ Social scientific studies of fracking have much to contribute to imperative discussions about energy futures, global climate change, and other definitive challenges of twenty-first century life. While the case studies included in this special section are diverse, contributors all aim to apply a holistic understanding of the human impacts of hydraulic fracking to the larger task of promoting the best possible future for our planet and the people who share it. Collectively, they underscore the fact that fracking-like other anthropogenic ecological disturbances-must be approached not only as an environmental issue, but as a cultural and political one as well.

\section{Contexts and connections}

Human experience is at the front line of changing technological, economic, and social conditions. Attending to local ethnographic detail as well as broad systemic inequity, the articles reveal that residents of

\footnotetext{
${ }^{3}$ The Journal of Environmental Studies and Sciences and Culture, Agriculture, Food, and Environment have published special issues on this topic in 2014 and 2013, spotlighting Marcellus Shale development and energy more broadly.

${ }^{4}$ Within the United States and internationally, policy decisions governing shale development have varied considerably. In the United States, recent regulatory changes have served to speed extraction in some states (e.g., Ohio and New Jersey), while others have effectively brought citizen and environmental perspectives to the table to encourage environmental and human health protection alongside resource development. New York and Maryland, for example, have moratoria in place that effectively postpone shale development, and Vermont has banned the practice outright. Similar diversity is seen internationally, with Australia, the United Kingdom, South Africa, and Poland eager to develop shale resources even as France and Bulgaria have banned such development (de Melo-Martín et al. 2014).
} 
geographically distributed and culturally distinct regions are experiencing strikingly similar situations. Unconventional energy extraction presents formidable challenges for those living in close proximity to it (Perry 2011, 2013; Wylie 2011). The lives of people in industrial supply areas, and consumers of energy, are also altered by changes in international production and distribution systems. Here, we identify common contexts, highlight unifying themes, and identify important opportunities for future research.

\section{Fracking in historical context}

Viewing celebratory television advertisements and passing billboards offering cash for subsurface leases (for those of us who are residents of fracking zones) or reflecting on the numerous public campaigns and policy battles fought by those who oppose unconventional energy extraction (for concerned citizens everywhere), it's easy to forget how recently fracking has arrived on the scene. In the second decade of the $21^{\text {st }}$ century, fracking has captured the interest not only of those individuals who confront its environmental, economic, and social effects directly, but also of scholars, advocates, and activists seeking to understand how emerging forms of unconventional resource extraction are resulting in new kinds of displacement and disempowerment, transforming relationships between people and technology, and altering relationships between people and the environments they inhabit.

Fracking is an outgrowth of established energy production patterns, as well as a novel socio-technical phenomenon. Even as it employs new processes and generates new hazards, fracking extends trajectories of physical and social impact initiated in earlier resource extractive eras. Unmapped, abandoned, and decaying infrastructure from previous oil and gas extraction are just one of the many failures of effective regulatory oversight that are being unearthed as debates over the health and safety of fracking unfold (Horwitt 2011). And, given that oil field wastes have historically been largely unregulated (EWG 2009), the expanding use of chemicals has brought significant media and public attention to the toxicity of oil and gas production. Ironically, public concern over the environmental and human health threats associated with fracking has served to open the industry to the potential for more effective monitoring. This is creating new avenues for state and federal oversight of fossil fuel extraction.

Previous phases of fossil fuel extraction (especially oil and coal) also provide a baseline for comparative/diachronic social analyses. Since the 1970s, rural sociologists have been investigating what is commonly known as the "boomtown" phenomenon or syndrome (e.g., England and Albrecht 1984; Freudenburg 1981; Gilmore 1976) in which rural areas experience rapid industrialization and population growth catalyzed by the discovery of natural resources. Researchers have found that the negative consequences of development often outweigh the advantages; even as the availability of jobs and local tax revenues increase, strains on physical infrastructure, housing, and social services combine with social disruption caused by rapid population growth and perceptions of environmental degradation to produce an overall decrease in community satisfaction (Anderson and Theodori 2009: 115). On the other hand, longitudinal studies have led some observers to propose a "boom-bust-recovery" cycle in which many of the initial problems associated with rapid growth are resolved over time (Brown et al. 2005; Rolston 2013). Although communities undergoing rapid increases in hydraulic fracking activity can be expected to follow the sequential social stages of boomtown development (enthusiasm- uncertainty-panic-adaptation), many of the current impacted areas have histories, topographies, environmental and economic conditions, and regulatory structures that differ considerably from those examined previously (Brasier et al. 2011: 37-38). Due to these differences and to the process's unique technological and social attributes, the current fossil fuel boom diverges from historical oil and gas production in important ways.

The effects of fracking on water resources, for instance, have been widely recognized as posing novel risks that differ from conventional oil and gas extraction (Merrill 2013). ${ }^{5}$ After the $11^{\text {th }}$ Circuit Court of Appeals ruled in 1997 that fracking should be regulated as a form of underground injection by the "plain language of the Safe Drinking Water Act," it appeared that emerging technology would be monitored

\footnotetext{
${ }^{5}$ The potential impacts on fresh water and ecosystems are immense (United States Environmental Protection Agency 2012). Millions of gallons of water are utilized in each fracking procedure, with scores of potentially harmful and/or carcinogenic chemicals injected into the ground, and flowback (a term used to describe the up to $70 \%$ of the fluid injected into a well that returns to the surface) that may contain naturally occurring radioactive materials (NORM).
} 
federally by the EPA and by individual states through Underground Injection Control (UIC) plans. UIC plans would have required state-level reporting of chemical hazards in fracking, monitoring, and protection of underground sources of drinking water (LEAF 1997). However, seeking to preserve their market niche and to expand the development of unconventional fossil fuel reserves, the oil field service industry successfully lobbied for an exemption to the Safe Drinking Water Act of 1974 as part of the 2005 Energy Policy Act (Wylie 2011; Wylie et al. 2014). Closing this loophole-sometimes referred to as the "Halliburton Loophole"—has been a subject of fierce debate.

Also layered upon a complex array of emerging public health and policy issues is the unique physical landscape of shale energy extraction. While conventional extraction involved seeking pockets of oil or gas trapped beneath a non-porous capstone, the oil and gas contained within shale formations is spread out in a matrix. The small seismic events produced by fracking create routes for this distributed gas to travel to the well. The implication is that any well drilled into a shale formation could potentially be made to produce, dramatically increasing the density of wells on the surface.

How, in this context, might the rapid intensification of fracking challenge the dynamics documented by boomtown researchers and transform our understandings of energy development's social effects? How do local histories of extraction and factors like gender, age, and class shape residents' reactions? These questions are particularly pertinent in locales with long resource extraction legacies, such as the Pennsylvania coal mining country discussed here and elsewhere by Anastasia Hudgins and Amanda Poole, where local residents draw stark contrasts between the emplaced family narratives of the coal mining past and the "disaggregated, transient, and nonunionized" labor and uneven costs-benefits distribution associated with ongoing fracking development (Hudgins 2013: 55; Hudgins and Poole 2014; Poole and Hudgins 2014).

\section{Fracking and embodied experience}

Because global patterns of energy extraction create as well as respond to local conditions, energopolitics (defined as "power over (and through) energy" (Boyer 2011: 5)) must be examined at multiple scales. At its most intimate, this means contemplating how fracking affects human bodies. Our bodies are our interface with the external world. And, as historian Joy Parr notes, "...our senses are the conduits through which knowledge of technology and the environment flow and, through retuning habit and reflex, the ways we habituate to our changing habitat" (2010: 1). Technology shapes our experience of the world in ways that are both positive and negative, both conscious and intuitive. For individuals on the ground, concerns about unconventional energy development are often initially evident through sensory experiences. Foul odors and discolored waters reveal the presence of potentially hazardous wastes, spills, and/or pollution. Our senses tell us when something is wrong. Deborah Davis Jackson coined the useful term dysplacement to underscore how perceptible pollution can transform formerly positive sensory experiences of place to experiences of profound alienation (Jackson 2011). In other words, even when people are not physically displaced, the sensory experience of environmental degradation can lead to equally damaging dysplacement.

Qualitative research in anthropology and related fields is uniquely positioned to address the experiential dimensions of energy development. To be sure, quantitative scientific research contributes in important ways to understanding the embodied effects of fracking. But exclusively quantitative projects are unable to account for personal narratives and the scientific discourse from which they derive may undermine or effectively delegitimize local residents' perspectives. As Melissa Checker argues, in many cases "perceptions of risk contrast sharply with official evaluations of risk" (Checker 2007: 113), with official pronouncements regularly disregarding residents' convictions that very serious problems exist. Concerned citizens of fracking zones are often discredited as irrational within the wider public discourse (Finewood and Stroup 2012; for a broader treatment of this issue see Button 2010). It is not enough, therefore, to collect samples and compile statistics; we need to tell real stories that speak to real people's experiences, to give voice to views that may otherwise remain unheard.

Several of the articles that follow tell such stories (Hudgins and Poole 2014; Simonelli 2014; Willow; 2014; Wylie and Albright 2014). In so doing, they concurrently-though usually implicitly-contest the universality of Western science by questioning who has the power to affirm the existence of hazard and risk. Regardless of which version of reality is officially accepted, residents of impacted areas respond according to 
their own perceptions and fears (Rappaport 1994). The surge in actual and impending environmental transformation resulting from fracking development has thus been met by an analogous surge in grassroots activism, a topic also addressed by articles in this special section (Mercer, de Rijke, and Dressler 2014; Simonelli 2014). Heeding calls to consider pollution as a form of social relation (Kirsch 2006: 220) and health as an ecological relation (Mitman 2007), the authors in this section work at the intersection of society, embodiment, and environment, thereby challenging modernist visions of an ontological separation of human culture from non-human nature (see Latour 1993).

\section{Fracturing communities, fostering connections}

As a new form of fossil fuel extraction, fracking has the capacity both to fracture formerly cohesive communities and to bring formerly disparate communities together. Wherever it takes place, fracking reshapes the social fabric. Local, state, and federal agencies are often overwhelmed by the pace of permitting and extraction and under-resourced to provide services to the communities experiencing it. These impacts are felt at the ground level, with landowners who encounter impacts (e.g., chemical spills on their property) forced to navigate bureaucratic warrens designed to reactively respond to hazards rather than proactively prevent them. The daily functioning, political machinations, and effectiveness of previously little-monitored and little-studied state and federal environmental resource and management agencies have become sites of contestation and intervention for proponents and critics alike. Especially in rural areas unzoned for certain land uses, few local regulations or regulatory bodies exist to intervene or influence extractive industrial development. This tends to encourage the rapid expansion of unconventional extraction and offers residents few opportunities to collectively contest or direct the development process.

Particular challenges are confronted by people who own the surface rights to their property but not the underlying subsurface minerals. Since mineral lease holders have the legal right to develop their resource, surface owners are frequently unable to participate in decisions concerning mineral development on their own property. Because leases negotiated by individual landowners are based on various categories of mineral or surface ownership, neighbors often have distinctly different experiences with the industry, with low-income surface owners and renters commonly experiencing the most detrimental effects. The resulting "divide and conquer" dynamic creates new divisions between community residents. Just as oil extraction companies operating in Ecuador deliberately deploy divide-and-conquer techniques to turn inhabitants against each other (in this case by differentially offering contracts for labor and land use to existing tribal groups and even working to constitute newly "authentic" ones) (Sawyer 2004), a similar process has deepened divisions between "haves" and "have nots" in fracking zones in the United States and elsewhere.

Interestingly, however, fracking is also creating unanticipated new connections between rural and urban areas as landowners in both places struggle with a loss of local control over their social, economic, and physical circumstances. For instance, suburban residents of Cleveland, Ohio have found themselves working with rural Texans and citizens' alliances from New Mexico (Wylie 2011), and impacted individuals in Pennsylvania and Colorado have found ways to share information through new digital forums (Wylie and Albright 2014). Grassroots coalitions are also reaching across national and state boundaries as local alliances and national nonprofits work to create community-to-community education and solidarity. Considering the notion of connection more literally, many of the environmental health debates surrounding fracking stem from concern that the subsurface fractures it generates could produce undesirable interconnections between gas-bearing formations and groundwater. The potential for surprising and unwelcome links have been the foundation for water contamination lawsuits and vitriolic disagreement between proponents of fracking who argue that the distances between aquifers and target formations is too great for contamination to occur (MITEI 2011) and critics who cite suppressed EPA studies showing how abandoned oil and gas wells can create such conduits to dispute this hardline separation (Horwitt 2011).

\section{Inaccessible places, inaccessible information}

Surface owners and residents of resource extraction zones are often the last to know about the shale reserves beneath their feet. In many instances, the industry is able to secure leases and access target resources before residents are able to mobilize resistance. It is therefore vital to examine the oil and gas 
industry systematically and structurally in order to understand how and why the isolation of surface owners is produced. Oil and gas extraction is typically marked by an enclaving process, through the establishment of what Andrew Barry (2005) calls "technological zones," to which only certain people have access and in which space and time are marked differently (Appel 2011; Bowker 1987; Ferguson 2005; Santiago 2006). Access to technological zones is limited to employees, and their distinction from the surrounding landscape is further emphasized by particular spatial and temporal arrangements. These technological zones have reached an extreme form in offshore oil-rigs, which are run on 24-hour cycles and staffed by workers pulling 12-hour shifts (Appel 2011).

Such enclaves form a crucial part of "oil ecologies" organized to channel oil and the wealth it generates from regions of extraction to regions of social and political power (Peluso and Watts 2001; Santiago 2006; Watts 2003, 2005). Writing of the Ecuadorian and Nigerian contexts, Watts describes "petroimperialism" as a Faustian pact in which "...a national project (modernity, development, civilization)...is purchased at the expense of sovereignty, autonomy, independence, tradition and so on" (Watts 2001: 205). Suddenly, through narratives that create networks across scales, a quiet and isolated rural region's fate is determined by global actors (Tsing 2005). Technological zones are a physical instantiation of these emerging global market relationships. These zones appear to be technically justified, but simultaneously hide their political and economic interests. Such disengaged or, as Appel (2011) describes them, "modular" technical arrangements provide for the perpetuation of an oil and gas industry in which alternative modes of life and populations in producing regions are continually made structurally irrelevant to the success of resource extraction. Whereas the structure of oil and gas development in the United States formerly stood as an exception to the enclaving practices developed in international and postcolonial contexts, these practices are now being re-imported into the United States to facilitate the present natural gas boom.

The current boom further differs from previous boom-bust cycles dependent upon the discovery and tapping of resources in new regions - not so much because of the nature of the technology itself, but because of the intellectual property associated with it. Hydraulic fracking is controlled by a unique and powerful subsector of the oil and gas industry, namely oil field services companies (Casselman 2008; Hamburger and Miller 2004; Nijhuis 2006). Beyond the emergence of new regimes for managing physical property, then, oil and gas development is sped by the drive to secure intellectual property, with prominent companies like Schlumberger and Halliburton now fighting vigorously to retain sole control over the processes and chemicals that make hydraulic fracking possible (Wylie 2011). These multinational corporations (which include some of the wealthiest in the world) make their money neither from owning territory nor from controlling pipelines, but from controlling intellectual property-in this case the technological knowledge associated with high-volume slick water horizontal hydrofracturing (Bowker 1994; Wylie 2011). This has important consequences for the public availability of information about the chemicals employed in fracking. The "Halliburton Loophole" exemption to the Safe Drinking Water Act, described above, means that companies are rarely required to report or monitor the chemicals they use. It has also prevented the Environmental Protection Agency from regulating the practice at the federal level.

\section{From a "down-hole" to a life-cycle approach}

Chemicals used in hydraulic fracking have become central to vociferous national and international debates about the health and safety of the ongoing unconventional fossil fuel boom. Concerns about the toxicity of these chemicals to humans and the environment are cited as primary causes for concern, as multiple articles in this special section confirm. At the same time, however, environmentalism's traditional focus on wildlife and protected area legislation makes it easier to prevent fracking in wilderness and other "natural" areas than in urban or rural locales. Analyses of environmentalism in Science and Technology Studies (STS), toxicology, and the field sciences have argued that the development of laboratory sciencealong with well-funded corporate chemical research and development programs-make it structurally difficult to link illness to chemical exposure (Langston 2010; Murphy 2006; Nash 2006; Oreskes and Conway 2010). Through "informated environmentalism" (Fortun 2004)—in which environmental organizations generate research and share data digitally_NGOs, citizens' alliances, and online organizations are contributing new ways to study and respond to the environmental health issues posed by fracking chemicals (see also Fortun 2011; Wylie 2011). New ways of producing and sharing environmental 
knowledge are emerging as communities organize "bucket brigades" and as citizen water monitoring projects and online mapping and databasing tools are developed in attempt to fill gaps in knowledge and monitor the true environmental and health impacts of fracking (Martinez-Alier et al. 2014; Penningroth et al. 2013; Steinzor et al. 2013; Wylie 2011). ${ }^{6}$

The fusion of embodied experience of the oil and gas industry and informated environmentalist efforts to document chemicals used in the hydraulic fracking process, connect those chemicals to health effects, and prove exposure and damage has inspired a shift from a limited "down hole" perspective on the safety of fracking to a life-cycle approach that empowers and interrelates local residents' experiences. As a result, the following calls are now being heard in activist, advocacy, and academic circles:

- Supply chain analyses are needed to address the widespread impacts of the unconventional fossil fuel boom, including the extraction of sand for proppants and the manufacture and storage of hazardous chemicals.

- A greater understanding of seismic imaging and leasing processes is required.

- Broad monitoring of fracking operations is needed, not only at well sites but also as energy development impacts truck traffic and the development of allied infrastructure such as roads, pipe-lines, and compressor stations.

- Further analysis and monitoring of waste disposal and storage-including injection wellsis imperative.

- Finally, longitudinal studies of the industry's social, environmental, economic, and political impacts must be pursued and their results connected to meaningful regulatory reforms.

How this extensive monitoring will be achieved is an open question that is currently being answered in the United States through citizen science as well as EPA and Presidential panel investigations. Given the importance of documenting fracking zone residents' experience across communities, qualitative researchers are uniquely situated to assist in advising, conceptualizing, coordinating, and conducting studies that make constructive sense of the cumulative effects of hydraulic fracking.

\section{The importance of ethnography}

Social scientific studies of unconventional energy development are well-positioned to begin building vital bridges between technical discourse and human experience. On the ground, qualitative ethnographic details can complement quantitative scientific risk-assessment processes and make underrepresented voices more audible (Checker 2005, 2007). While individual scholars will undoubtedly continue to choose their own paths, many seem to agree that we have a moral and ethical duty to bear witness when injustice impacts those with whom we work and from whom we learn (Healy 2014). Stuart Kirsch, who has worked extensively with Yonngom residents of New Guinea affected by the environmentally and culturally devastating Ok Tedi mine, suggests that "by documenting political violence and representing its human costs, anthropologists can amplify indigenous forms of political expression, bring the resources of the discipline and the moral weight of the academy to bear on injustice" (Kirsch 2006: 187). In the case of fracking, "indigenous" expressions are also often our own (Simonelli 2014).

In the first featured article, "The new politics of environmental degradation: Un/expected landscapes of disempowerment and vulnerability," Anna Willow (2014) investigates connections between fracking in the Midwestern United States and indigenous experiences of environmental injustice. The article begins in the author's home state of Ohio, where citizens are discovering their lack of ability to influence the expansion of

\footnotetext{
${ }^{6}$ For information on some of these projects, see:

- The Endocrine Disruption Exchange: www.endocrinedisruption.com/chemicals.introduction.php

- FracTracker: http://www.fractracker.org/

- Global Community Monitor: http://www.gcmonitor.org/section.php?id=224

- Skytruth: http://blog.skytruth.org/2012/11/skytruth-releases-fracking-chemical.html
} 
shale gas into their communities. The surprising similarity between emerging middle-class vulnerability to environmental degradation and Willow's prior ethnographic work documenting chronic environmental injustices experienced by an Anishinaabe First Nation in Canada triggers her theoretical analysis of unconventional energy extraction as a neoliberal process of environmental and social dispossession. Focusing on the experience of environmental degradation as a hallmark of changing social position, Willow investigates a troubling and potentially socio-politically transformative new parity between middle-class Americans and indigenous communities. She argues that

...even as distinctive historical and cultural contexts set these situations apart, common perceptions of disempowerment and vulnerability seem to suggest extensive systemic changes, as growing numbers of people from increasingly diverse walks of life are now being forced to face immediate-and often very serious-environmental challenges that they did not authorize and do not benefit from (p. 240).

In "Home rule and natural gas development in New York: civil fracking rights", by Jeanne Simonelli, we learn about New York State residents' response to fracking and to the infrastructure connected to it. Simonelli (2014) reviews the growth of a social movement for civil rights and home rule that has accompanied oil and gas development. A longtime resident of the region, the author explores how community understanding of the impact and infrastructure associated with hydraulic fracking has translated into social action within the social, political and ecological context of rural New York. She uses actual and virtual interviews and oral histories to provide a case study of a struggle for environmental justice amidst conflicting visions and experiences of rural life in one New York region in order to show how "individual townships in the shale gas regions of the state have used home rule in an attempt to chart their own development course" (p. 263). Intersecting with Willow's analysis, the author notes, this movement has built upon listservs, websites, and protest tactics similar to those developed by the Zapatistas in Mexico. Accordingly, Simonelli looks to the global context, noting that although the historical and political conditions surrounding the Zapatista movement and the NY anti-fracking movements are different—and injustice is on a different scale-the threat to life and lifestyle gives rise to similar long term responses. Individuals have come together to learn to use the legal and political power available to them, in the interest of a collective struggle for both the local and global environment.

Transporting readers to the other side of the globe (but remaining as relevant in the North American context as the preceding articles are elsewhere), Alexandra Mercer, Kim de Rijke, and Wolfram Dressler (2014), authors of "Silence in the midst of the boom: coal seam gas, neoliberalizing discourse, and the future of regional Australia", employ text-based critical discourse analysis to examine the similarities and differences apparent in documents produced by the oil and gas industry, the Queensland state government, and a social movement called Lock the Gate. Approaching neoliberalism as an unfolding process, the authors demonstrate how both industry and government construe economic decisions as apolitical and see engaging with political questions as threatening "good economic outcomes" (p.286). Lock the Gate, in contrast, calls on decision-makers to take a myriad of non-economic issues (e.g., health, food, water) into account, thus challenging the neoliberalizing "economy is everything" perspective associated with the coal seam gas industry and the government that supports it.

Calling attention to the development of local social movements in response to fracking, the relevance of environmental and social justice perspectives, and anthropology's distinctive appreciation for the primacy of human experience, these articles show that the structural disempowerment that accompanies fracking is not an isolated local phenomenon, but is instead shared by residents of distant places who possess diverse cultural backgrounds and different personal interests. Through rich ethnographic narratives, the intensely stressful nature of the fracking process as well as the ongoing fear, uncertainty, and confusion it causes are made tangible. Fracking, these articles clearly demonstrate, goes far beyond the well that is drilled and fractured; it is also - and, we believe, even more importantly, like all issues interrogated from a political ecology perspective-about a much broader set of interrelated political, ecological, and social impacts. Finally, these articles encourage us to think in new ways about the now commonplace notion that people 
understand the environment in very different ways. Fracking reveals existing differences in how people construct, conceive, and know "nature" and exposes human-environment relationships as constantly in flux. Today's technological changes are transforming physical environments as well as relationships among environmental, social, and political elements of our world that were formerly perceived as disparate. Although it has not always been recognized, these elements have always been interconnected. We are now realizing, confronting, and contemplating these connections in new and urgent ways, as they are transformed before our eyes.

\section{Methodological innovations}

Together, the articles in this special section illustrate how collaborative activities and communication networks can shed new light on wider structural and systemic issues that are currently being experienced at the individual level. Some contributing authors are reaching for new ethnographic methods that empower concerned citizens to control and comprehend the impacts of unconventional energy development on social, political, and economic lives and on physical and cultural landscapes.

The fourth featured article, "Framing fracking: private property, common resources, and regimes of governance," by Anastasia Hudgins and Amanda Poole (2014), examines new forms of neoliberal industrial governance emerging in the context of Marcellus Shale drilling in Pennsylvania. Like the article by Mercer, de Rijke, and Dressler, it describes how industry-often in concert with state government-demands impacted individuals "reframe their human needs and desires to parallel those of capital" (p.305) and shows how forms of expertise that are not amenable to the interests of industry are effectively shut out. Building on previous analyses of the relationship between the state, capital, and civil society, Hudgins and Poole offer a case study that illustrates how political processes are able to convert manufactured consent into actionable legislation. They argue that a "new regime" is emerging in rural Pennsylvania, as land, water, and people are re-categorized, resistance minimized, and profit maximized (p. 304). Hudgins and Poole also suggest that the discourse of patriotism and job creation constructed by proponents of shale gas development obscures troubling realities and inequities - a problem also recognized by other authors in this Section. Based on innovative methodology involving the development of an ethnographic field school for students at the Indiana University of Pennsylvania (held in the summer of 2012), Hudgins and Poole's work demonstrates how local students can become involved in ongoing debates about unconventional energy development. By facilitating a field school, a unique opportunity was created for communities to comprehend and reflect upon shared interests and structural differences.

"WellWatch: reflections on designing digital media for multi-sited para-ethnography," by Sara Wylie and Len Albright (2014), also draws on and describes innovative ethnographic methods. Wylie and Albright consider the role of digital media in developing new networked approaches to oil and gas industry monitoring by concerned citizens and academics. They argue that " networked online databases provide a methodological framework for responsive community-based academic research " (p. 323). As "...both a research tool and intervention" (p.341), the WellWatch project allowed residents impacted by oil and gas development to post personal stories and to connect with others experiencing similar situations in an attempt to "intervene in the technical and informational asymmetries between [the oil and gas] industry and impacted landowners by developing closer relationships between communities and academics and developing free, open source tools for communities and community organizations" (p. 324). As the article details, WellWatch proved useful for affected individuals and community members as well as for researchers seeking to understand the impacts of energy development. The construction of a new kind of digital infrastructure allowed people in locations as distant as Pennsylvania and Colorado to speak for themselves and to compare their own health impacts, feelings of vulnerability and fear, and experiences of corporate/government negligence with others.

\section{Conclusion: changing roles, changing scholarship}

That the number of engaged scholars turning their attention to hydraulic fracking and other forms of resource extraction is rising rapidly speaks to an ongoing transformation in how we define our roles, how we conduct our work, and how we construct our fields of study. It is our hope that the pieces presented here- 
along with those of others who seek to give their scholarship similar substance-contribute not only to enriching our collective knowledge about humanity and the world we share but also to constructive ways of envisioning and enacting a positive future. Over three decades ago, Laura Nader made an apt observation: "The energy problem is not a technological problem," she wrote, "it's a social problem" (1982: 104). This point is more relevant than ever.

While each of these articles can be appreciated independently, reading this theoretically and methodologically diverse Special Section as a single entity leads to additional insights. The articles included here illustrate how multiple methodological approaches-ranging from field school facilitation and technologically-assisted online ethnography to text/media-based discourse analysis and participantobservation/interview strategies — can elicit rich ethnographic data to reveal striking similarities in the social, cultural, and political impacts of oil and gas development as it plays out across time and space. Contributors are forging new fieldwork trajectories based upon collaborative research philosophies. All of the included articles seek to connect academic work and advocacy. All constitute vehicles for sharing human experience. And, all are frankly critical of neoliberal economic policy, industrial domination, and the displacement of human concerns that appears to follow unconventional energy development wherever it goes. Some authors use writing as a primary strategy for creating these connections (e.g., Mercer, de Rijke, and Dressler 2014; Simonelli 2014; Willow 2014), constructing critical analyses and narratives that question the current state of affairs. Others (e.g., Hudgins and Poole 2014; Wylie and Albright 2014) have concurrently developed active and empowering new platforms for community collaboration that break down the structural barriers that too often separate not only industry/government and citizens, but also citizens and academics.

The barriers that once existed between scholarship and advocacy-reflected in purported divisions between academic and applied social science-are being broken down (Checker and Fishman 2004; Ginsburg 2004). The articles featured in this collection forge links between these formerly isolated ways of knowing the world, thus contributing to important conversations about the future of academia. Given that many of us are employed by universities, we are compelled to ask what engaged scholarship means when universities are leasing land for unconventional energy development (or considering doing so). What does it mean when many university departments and centers are structurally embedded in scientific and technical developments that seek to increase energy extraction? And, more broadly, what does it mean when researchers are also residents of impacted areas who sometimes have pressing and highly personal motives for exploring energy extraction? Together, the articles in this Special Section begin to answer these important questions and chart a course toward an engaged anthropology of energy that is emerging in zones of hydraulic fracking, and in other places where resource-extractive industrial development is changing lives.

\section{Energy, environment, engagement: encounters with hydraulic fracking Edited by Anna Willow and Sara Wylie}

1. Anna J. Willow and Sara Wylie: Introduction to the special section: Politics, ecology, and the new anthropology of energy: exploring the emerging frontiers of hydraulic fracking

2. Anna J. Willow: The new politics of environmental degradation: un/expected landscapes of disempowerment and vulnerability

3. Jeanne Simonelli: Home rule and natural gas development in New York: civil fracking rights

4. Alexandra Mercer, Kim de Rijke, and Wolfram Dressler: Silence in the midst of the boom: coal seam gas, neoliberalizing discourse, and the future of regional Australia

5. Anastasia Hudgins and Amanda Poole: Framing fracking: private property, common resources, and regimes of governance

6. Sara Wylie and Len Albright: WellWatch: reflections on designing digital media for multi-sited paraethnography 


\section{References}

Appel, H. 2011. Futures: oil and the making of modularity in Equatorial Guinea. PhD Dissertation, Department of Anthropology, Stanford University.

Anderson, B.J. and G.L. Theodori. 2009. Local leaders' perceptions of energy development in the Barnett Shale. Southern Rural Sociology 24(1): 113-129.

Barry, A. 2006. Technological zones. European Journal of Social Theory 9(2): 239-253.

Bowker, G.C. 1987. A well ordered reality: aspects of the development of Schlumberger, 1920-39. Social Studies of Science 17(4): 611-655.

Bowker, G.C. 1994. Science on the run: information management and industrial geophysics at Schlumberger, 1920-1940. Cambridge, MA: MIT Press.

Boyer, D. 2011. Energopolitics and the anthropology of energy. Anthropology News 52(5): 5-7.

Brasier, K.J., M.R. Filteau, D.K. McLaughlin, J. Jaquet, R.C. Stedman, T.W. Kelsey, and S.J. Goetz. 2011. Residents' perceptions of community and environmental impacts from development of natural gas in the Marcellus Shale: a comparison of Pennsylvania and New York Cases. Journal of Rural Social Science 26(1): 32-61.

Brown, R.B., S.F. Dorins, and R.S. Krannich. 2005. The boom-bust-recovery cycle: dynamics of change in community satisfaction and social integration in Delta, Utah. Rural Sociology 70(1): 28-49.

Button, G. 2010. Disaster culture: knowledge and uncertainty in the wake of human and environmental catastrophe. Walnut Creek, CA: Left Coast Press.

Cartwright, E. 2013. Eco-risk and the case of fracking. In S. Strauss, S. Rupp, and T. Love (eds.) Cultures of energy: power, practices, technologies. Walnut Creek, CA: Left Coast Press. Pp201-212.

Casselman, B. 2008. Corporate news: oil-field services firms prosper on drilling boom. Wall Street Journal (Eastern edition), July 23 2008, sec. B3.

Checker, M. 2005. Polluted promises: environmental racism and the search for justice in a southern town. New York: New York University Press.

Checker, M. 2007. "But I know it's true": environmental risk assessment, justice, and anthropology. Human Organization 66(2): 112-124.

Checker, M. and M. Fishman. 2004. Introduction. In M. Checker and M. Fishman (eds.) Local actions: cultural activism, power, and public life in America. New York: Columbia University Press. Pp1-25.

De Rijke, K. 2013a. Hydraulically fractured: unconventional gas and anthropology. Anthropology Today 29(2): 13-17.

De Rijke, K. 2013b. The Agri-gas fields of Australia: black soil, food and unconventional gas. Culture, Agriculture, Food, and Environment 35(1): 41-53.

De Melo-Martín, I., J. Hays, and M.L. Finkel. 2014. The role of ethics in shale gas policies. Science of the Total Environment 470-471: 1114-1119.

England, J.L. and S. Albrecht. 1984. Boomtowns and social disruption. Rural Sociology 49(2): 230-246.

Entrekin, S., M. Evans-White, B. Johnson, and E. Hagenbuch. 2011. Rapid expansion of natural gas development poses a threat to surface waters. Frontiers in Ecology 9(9): 503-511.

EWG (Environmental Working Group). 2009. Free pass for oil and gas: environmental protections rolled back as western drilling surges: oil and gas industry exemptions. Online [accessed December 16 2013]. http: //www.ewg.org/news/news-releases/2009/03/26/free-pass-oil-and-gas-environmentalprotections-rolled-back-western.

Ferguson, J. 2005. Seeing like an oil company: space, security, and global capital in neoliberal Africa. American Anthropologist 107(3): 377-382.

Finewood, M.H. and L.J. Stroup. 2012. Fracking and the neoliberalization of the hydro-social cycle in Pennsylvania's Marcellus Shale. Journal of Contemporary Water Research and Education 147(1): 7279. 
Fortun, K. 2004. From Bhopal to the informating of environmentalism: risk communication in historical perspective. Osiris 19: 283-296.

Fortun, K. 2011. Biopolitics and the informating of environmentalism. In Kaushik, S.R. (ed.) Lively capital. Durham, NC: Duke University Press. Pp283-296.

Freudenburg, W.R. 1981. Women and men in an energy boom town: adjustment, alienation, and adaptation. Rural Sociology 46: 220-44.

Gilmore, J.S. 1976. Boom towns may hinder energy resource development: isolated rural communities cannot handle sudden industrialization and growth without help. Science 191: 535-540.

Ginsburg, F. 2004. Forword. In M. Checker and M. Fishman (eds.), Local actions: cultural activism, power, and public life in America. New York: Columbia University Press. Ppix-xvii.

Hamburger, T. and A.C. Miller. 2004. Halliburton's interests assisted by White House: the administration has lent support to a lucrative drilling technique: some in the EPA consider it an environmental concern. Los Angeles Times. October 142004.

Healy, S. 2014. The biopolitics of community economies in the era of the Anthropocene. Journal of Political Ecology 21: 210-221.

Holzman, D. 2011. Methane found in well water near fracking sites. Environmental Health Perspectives 119(7): a289

Horwitt, D. 2011. Cracks in the façade: 25 years ago EPA linked fracking to water contamination. Environmental Working Group. Online [accessed December 16 2013]. http: //static.ewg.org/reports/2011/fracking/cracks in the facade.pdf.

Howarth, R.; R. Santoro, and A. Ingraffea. 2010. Methane and the Greenhouse-gas footprint of natural gas from shale formations. Climatic Change 105(4): 679-690.

Hudgins, A. 2013. Fracking's future in a coal mining past: subjectivity undermined. Culture, Agriculture, Food, and Environment 35(1): 54-59.

Hudgins, A. and A. Poole. 2014. Framing fracking: private property, common resources, and regimes of governance. Journal of Political Ecology 21: 303-319.

Jackson, D.D. 2011. Scents of place: the dysplacement of a First Nations community in Canada. American Anthropologist 113(4): 606-618.

Jackson, R.B., A. Vengosh, T.H. Darrah, N.R. Warner, A. Down, R.J. Poreda, S.G. Osborn, K. Zhao, and J.D. Karr. 2013. Increased stray gas abundance in a subset of drinking water wells near Marcellus shale gas extraction. Proceedings of the National Academy of Sciences 110(28): 11250-11255.

Jacquet, J.B. 2012. Landowner attitudes toward natural gas and wind farm development in northern Pennsylvania. Energy Policy 50: 677-688.

Kirsch, S. 2006. Reverse anthropology: indigenous analysis of social and environmental relations in New Guinea. Stanford, CA: Stanford University Press.

Langston, N. 2010. Toxic bodies: endocrine disruptors and the lessons of history. New Haven, CT: Yale University Press.

Latour, B. 1993. We have never been modern. Cambridge, MA: Harvard University Press.

Legal Environmental Assistance Foundation (LEAF). 1997. Legal Environmental Assistance Foundation Inc. v. United States Environmental Protection Agency. 45 ERC 1033, 27 Envtl. L. Rep. 21,385, 11 Fla. L. Weekly Fed. C 335 No. 95-6501. United States Court of Appeals, Eleventh Circuit. Aug. 7. 118 F3d 1467.

Martinez-Alier J., Anguelovski I., Bond P., Del Bene D., Demaria F., Gerber J.-F., Greyl L., Haas W., Healy H., Marín-Burgos V., Ojo G., Porto M., Rijnhout L., Rodríguez-Labajos B., Spangenberg J., Temper L., Warlenius R. and I. Yánez. 2014. Between activism and science: grassroots concepts for sustainability coined by Environmental Justice Organizations. Journal of Political Ecology 21: 19-60.

McKenzie, L.M., R.Z. Witter, L.S. Newman, and J.L. Adgate. 2012. Human health risk assessment of air emissions from development of unconventional natural gas resources. Science of the Total Environment 424: 79-87. 
McKibben, B. 2011. The ugliest word in the English language: fracking. Sojourners. Online June20 2011 [accessed January 12 2013]. http: //sojo.net/blogs/2011/06/20/ugliest-word-english-language-fracking.

Mercer, A., K. de Rijke, and W. Dressler. 2014. Silence in the midst of the boom: coal seam gas, neoliberalizing discourse, and the future of regional Australia. Journal of Political Ecology 14: 279302.

Merrill, T. 2013. Four questions about fracking. Case Western Reserve Law Review 63(4): 970-993.

MITEI (MIT Energy Initiative). 2011. The future of natural gas: an interdisciplinary MIT study. Cambridge, MA: MITEI.

Mitman, G. 2007. Breathing space: how allergies shape our lives and landscapes. New Haven, CT: Yale University Press.

Murphy, M. 2006. Sick building syndrome and the politics of uncertainty: environmental politics, technoscience and women workers. Durham, NC: Duke University Press.

Nader, N. 1981. Barriers to thinking new about energy. Physics Today 34(9): 99-104.

Nash, L. 2006. Inescapable ecologies: a history of environment, disease and knowledge. Berkeley: University of California.

Nijhuis, M. 2006. How Halliburton technology is wrecking the Rockies. On Earth Magazine. Summer.

Oreskes, N. and E.M. Conway. 2010. Merchants of doubt: how a handful of scientists obscured the truth on issues from tobacco smoke to global warming. New York: Bloomsbury Press.

Osborn, S.G., A.Vengosh, N.R. Warner, and R.B. Jackson. 2011. Methane contamination of drinking water accompanying gas-well drilling and hydraulic fracturing. Proceedings of the National Academy of Sciences 108(20): 8172-8176.

Parr, J. 2010. Sensing changes: technologies, environments, and the everyday, 1953-2003. Seattle: University of Washington Press.

Pearson, T.W. 2013. Frac sand mining in Wisconsin: understanding emerging conflicts and community organizing. Culture, Agriculture, Food, and Environment 35(1): 30-40.

Peluso, N. and M.J. Watts (eds.). 2001. Violent environments. Ithaca, NY: Cornell University Press.

Penningroth, S.M., M.M. Yarrow, A.X. Figueroa, R.J. Bowen, and S. Delgado. 2013. Community based risk assessment of water contamination from high-volume horizontal hydraulic fracturing. New Solutions. 23(1): 137-166.

Perry, S.L. 2011. Energy consequences and conflicts across the global countryside: North American agricultural perspectives. Forum on Public Policy 2011(2). Online [accessed September 29 2011]. http: //forumonpublicpolicy.com/vol2011.no2/archivevol2011.no2/perry.pdf.

Perry, S.L. 2013. Using ethnography to monitor the community health implications of onshore unconventional oil and gas developments: examples from Pennsylvania's Marcellus Shale. New Solutions 23(1): 33-53.

Poole, A. and A. Hudgins. 2014. "I care more about this place, because I fought for it": exploring the political ecology of fracking in an ethnographic field school. Journal of Environmental Sciences and Studies 4 (1): 37-46.

Rappaport, R.A. 1994. Human environment and the notion of impact. In B.R. Johnston (ed.) Life and death matters: humans rights and the environment at the end of the millennium. Walnut Creek, CA: AltaMira. Pp157-169.

Rolston, J.S. 2013. Specters of syndromes and the everyday lives of Wyoming energy workers. In S. Strauss, S. Rupp, and T. Love (eds.), Cultures of energy: power, practices, technologies. Walnut Creek, CA: Left Coast Press. Pp213-226.

Santiago, M.I. 2006. The ecology of oil: environment, labor and the Mexican revolution 1900-1938. Cambridge: Cambridge University Press.

Sawyer, S. 2004. Crude chronicles: indigenous politics, multinational oil and neoliberalism in Ecuador. Durham, NC: Duke University Press. 
Simonelli, J. 2014. Home rule and natural gas development in New York: civil fracking rights. Journal of Political Ecology 14: 258-278.

Steinzor, N., W. Subra, and L. Sumi. 2013. Investigating links between shale gas development and health impacts through a community survey project in Pennsylvania. New Solutions 23(1): 55-83.

Theodori, G.L. 2009. Paradoxical perceptions of problems associated with unconventional natural gas development. Southern Rural Sociology 24(3): 97-117.

Tsing, A. 2005. Friction: an ethnography of global connection. Princeton, NJ: Princeton University Press.

United States Environmental Protection Agency. 2012. Study of the potential impacts of hydraulic fracturing on drinking water resources: progress report. Online [accessed December 29 2012]. http://www.epa.gov/hfstudy/pdfs/hf-report20121214.pdf.

Watts, M.J. 2001. Petro-violence: Community, extraction, and political ecology of a mythic commodity. In N. Peluso and M.J. Watts (eds.) Violent environments. Ithaca, NY: Cornell University Press. Pp189212.

Watts, M.J. 2003. Economies of violence: more oil, more blood. Economic and Political Weekly 38(48): 5089-5099.

Watts, M.J. 2005. Righteous oil? Human rights, the oil complex and corporate social responsibility. Annual Review of Environment and Resources 30: 373-407.

Willow, A. 2014. The new politics of environmental degradation: un/expected landscapes of disempowerment and vulnerability. Journal of Political Ecology 21: 237-257.

Willow, A.J., D. Vilaplana, D. Sheeley and R. Zak. 2014. The contested landscape of unconventional energy development: a report from Ohio's shale gas country. Journal of Environmental Sciences and Studies 4(1): 56-64.

Wylie, S. 2011. Corporate bodies and chemical bonds: an STS analysis of natural gas development in the United States. PhD Dissertation. Cambridge, MA: Massachusetts Institute of Technology.

Wylie, S. and L. Albright. 2014. WellWatch: reflections on designing digital media for multi-sited paraethnography. Journal of Political Ecology 21: 320-348.

Wylie, S., K. Jalbert, S. Dosemagen, and M. Ratto. 2014. Institutions for civic technoscience: how critical making is transforming environmental research. The Information Society: an International Journal 30(2): 116-126. 